\title{
深層混合処理とジオテキスタイル併用工法による 軟弱地盤上盛土の現地動的繰返し載荷試験結果の検証解析
}

\author{
（財）鉄道総合技術研究所 小島謙一・舘山 勝 台湾成功大学 黄 景川 \\ 日本鉄道建設公団 青木一二三・米澤豊司・村上 明
}

腐植土層が堆積する軟弱地盤上に鉄道盛土を構築するにあたって, 鉄道開業後の沈下を極力抑制するた めに深層混合処理工法とジオテキスタイルとを併用して盛土を施工している. 本工法においては, 列車荷 重を含めた上載荷重載荷時における擋汼混合杭の間隔とジオテキスタイルに生じるひずみ等の関係, 未改 良部との不同沈下の抑制効果など, 静的および動的荷重状態での盛土や地盤の挙動を把握する必要が生じ た。これらを検討するために現場において各種計測計器を設置し, 列車走行を模擬した軌道繰返し衝撃試 験機による動的載荷試験を実施した．加えて長期計測や解析等を行い合理的な設計方法を提案することと した.

本論文は, 現地動的繰返し載荷試験結果をもとに有限差分法を用いて解析を行い, 盛土や地盤の挙動, 擋汼混合杭とジオテキスタイルの効果を評価するものである.

A numerical analysis of dynamic loading tests of the method to lay geosynthetic sheets on the soil cement columns for soft ground

\author{
K. Kojima and M. Tateyama : Railway Technical Research Institute \\ C.C.Huang : National Cheng Kung University
}

H. Aoki, T. Yonezawa and A. Murakami : Japan Railway Construction Public Corporation

Tohoku shinkansen is now being constructed on a very soft ground in the Hachinohe area. In this site, large settlement is predicted to occur on embankments under construction. We applied the geosynthetic sheet and soil cement column method to this site to decrease settlement of the ground. We tried two approaches to use this method; One is a dynamic loading test on the site, and the other is a numerical analysis of this site test.

This paper shows the numerical analysis of the dynamic loading test. We describe the normal stress and displacement of the ground, and tensions of geosynthetic sheets after dynamic loading. 


\section{深層混合処理とジオテキスタイル併用工法による 軟弱地盤上盛土の現地動的繰返し載荷試験結果の検証解析}

（財）鉄道総合技術研究所 小島謙一・舘山 勝 台湾成功大学 黄 景川

日本鉄道建設公団＼cjkstart青木一二三・米澤豊司・村上＼cjkstart明

\section{1.はじめに}

腐植土層が堆積する軟弱地盤上に鉄道盛土を構築するにあたって, 鉄道開業後の沈下を極力抑制するた めに深層混合処理工法とジオテキスタイルとを併用して盛土を施工している．本工法においては，擋汼混 合杭の間隔とジオテキスタイルに生じるひずみ等の関係，未改良部との不同沈下の抑制効果など摚汼混合 杭とジオテキスタイルの配置と効果について静的および動的荷重状態での盛土や地盤の挙動を把握する必 要がある.これらを検討するために現場において各種計測計器を設置し, 列車走行を模擬した軌道繰返し 衝撃試験機による動的載荷試験を実施し ${ }^{1)}$, 載荷試験結果をもとに有限差分法を用いて検証解析を行い, 盛土や地盤の挙動, 擋汼混合杭やジオテキスタイルの効果を評価するものである.

\section{2.現場概要}

当現場は, 東北新幹線盛岡一八戸間における八戸電 留線盛土である．盛土材料は現場周辺で得られた山砂 を用い，盛土高さは $1.0 \mathrm{~m} \sim 4.0 \mathrm{~m}$ 程度である.図-1に現 場地盤の柱状図を示す．地表面から深さ約 $4 \mathrm{~m}$ の位置に 非常に軟弱な腐植 土層があり, 盛土施 エに伴い大きな沈 下が想定された。し たがって, 盛土施工 後の残留沈下を極 力抑制するために 深層混合処理工法 を用いて腐植土層 を改良し沈下を軽 減することとした。 また，施工性・経済 性を考慮して深層 混合処理工法に 2 軸 の施工機を採用し たため，線路直角方

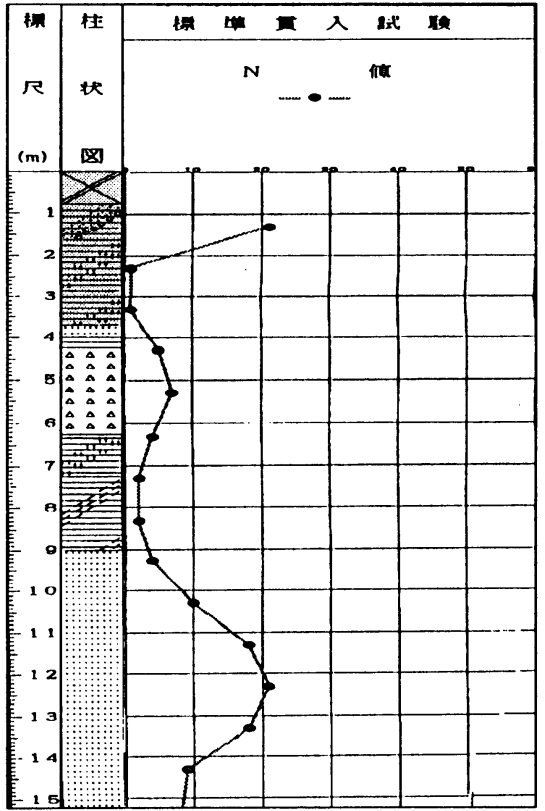

図-1＼cjkstart地盤柱状図

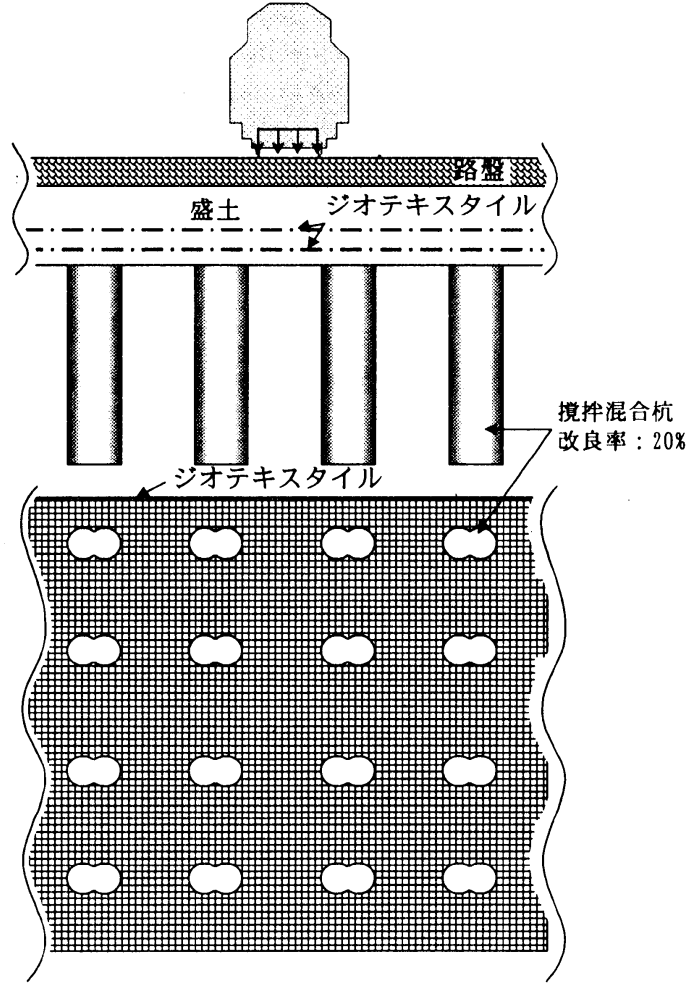

図-2 当現場における工法概要 
向の改良杭の純間隔が $1.5 \mathrm{~m}$ となり, 部分的に盛土高さよりも大きくなる箇所が生じた. そのため, 低盛土 部においては，改良部と末改良部にかかる応力差が大きくなり，パンチング破壊が起こることが眯念され た.よって, 盛土内のパンチングによる変形を防ぐ工法として, ジオテキスタイルを敷設し盛土荷重を分 散させる工法を採用した．図-2に盛土概要図を示す。本現場では，パンチング防止のジオテキスタイル材 料として引張強度が $60 \mathrm{kN} / \mathrm{m}$ の材料を地盤面から $0.3 \mathrm{~m}$ と $0.6 \mathrm{~m}$ の高さに2層にわたり配置した. 図-3に現場 における動的載荷試験の概要図を示す。なお, 動的載荷実験の詳細については文献(1)に詳しい.

3.動的載荷実験のシミュレーション

\section{1 数値解析概要}

数值解析は, 2次元有限差分法を用いて行った。図-3に 本解析で用いたモデル図を示す．モデルは線路直角方向を モデル化した断面であり, 計算の効率化を図るため半断面 とした．計算誤差を少なくするために地盤，盛土および擋 汼混合杭は四角形でモデル化を行った．路盤及び盛土は現 場の試験の状況に合わせ半無限地盤とした.ジオテキスタ イルには線形のケーブル要素を用いた. ジオテキスタイル と地盤の境界部にはインターフェースを用い, ジオテキス タイルが地盤内をすり抜けないという仮定の下で，圧縮， せん断バネともに $1 \times 10^{+7} \mathrm{kPa} / \mathrm{m}$ を用いた．表-1に各種材 料の入力パラメータを示す。地盤や盛土，擋汼混合杭は Mohr-Coulombの破壊規準に準じた弾完全塑性体とした. ジオテキスタイルについては断面積 $=1.5 \times 10^{-4} \mathrm{~m}^{2} / \mathrm{m}$, 変形 係数 $=1.0 \times 10^{+7} \mathrm{kPa}$, 引張降伏応力 $=60 \mathrm{kN} / \mathrm{m}$ とした.
列車荷重（起振機）

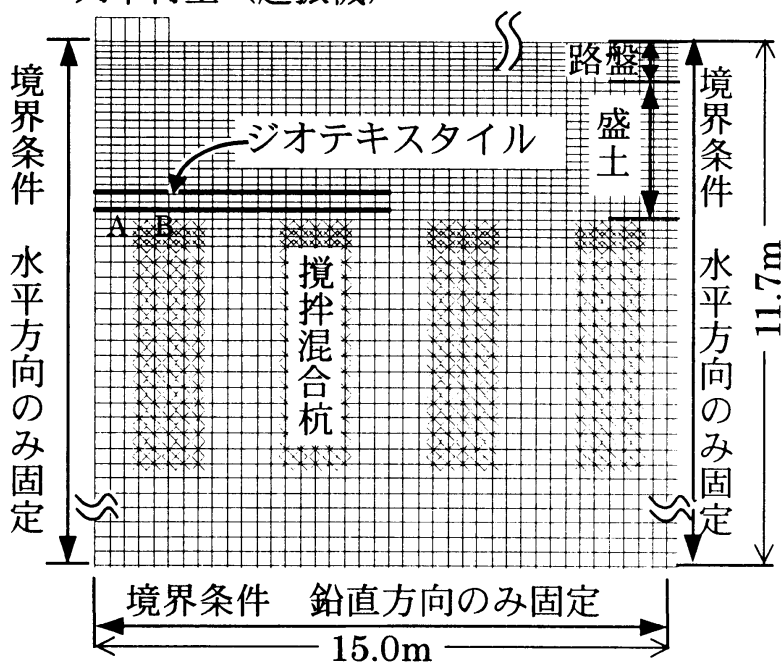

図-3 解析モデル図

表-1 入力パラメータ

\begin{tabular}{|c|c|c|c|c|c|c|}
\hline 材料 & $\begin{array}{c}\text { 密度 } \\
(\mathrm{t} / \mathrm{m} \\
3\end{array}$ & ポアソン比 & $\begin{array}{c}\text { せん断剛性 } G_{\text {max }} \\
(\mathrm{kPa})\end{array}$ & $\begin{array}{c}{\text { 変形係数 } E_{\max }}_{(\mathrm{kPa})}\end{array}$ & $\begin{array}{c}\text { 粘着力c } \\
(\mathrm{kPa})\end{array}$ & $\begin{array}{c}\text { 内部摩擦角 } \phi \\
\text { (度) }\end{array}$ \\
\hline 粒調砕石（路盤） & 2.0 & 0.25 & $1.20 \times 10^{+5}$ & $3.00 \times 10^{+5}$ & 0 & 45 \\
\hline 砂（盛土） & 1.8 & 0.3 & $5.42 \times 10^{+4}$ & $1.41 \times 10^{+5}$ & 0 & 40 \\
\hline $\begin{array}{c}\text { 腐植土 } \\
0.8 \sim 3.8 \mathrm{~m} \text { (地盤) }\end{array}$ & 1.1 & 0.4 & $5.78 \times 10^{+3}$ & $8.25 \times 10^{+3}$ & 10 & 5 \\
\hline $\begin{array}{c}\text { 軽石 } \\
3.8 \sim 6.2 \mathrm{~m} \text { (地盤) } \\
\end{array}$ & 1.5 & 0.3 & $9.60 \times 10^{+4}$ & $2.50 \times 10^{+5}$ & 0 & 20 \\
\hline $\begin{array}{c}\text { シルト質粘性土 } \\
6.2 \sim 9.0 \mathrm{~m} \text { (地盤) }\end{array}$ & 1.5 & 0.4 & $1.19 \times 10^{+4}$ & $1.71 \times 10^{+4}$ & 10 & 15 \\
\hline $\begin{array}{c}\text { コンクリート } \\
\text { (載荷板) }\end{array}$ & 2.4 & 0.2 & $9.79 \times 10^{+6}$ & $2.35 \times 10^{+7}$ & - & - \\
\hline $\begin{array}{l}\text { ソイルセメント } \\
\text { (擋找混合杭) }\end{array}$ & 1.5 & 0.25 & $2.15 \times 10^{+6}$ & $5.38 \times 10^{+6}$ & 200 & 45 \\
\hline
\end{tabular}


境界条件は底面では水平方向のみ固定，底面では鈶直方向のみ固定とした．動的解析時には底面及び端部 側面において水平・鈶直とも粘性境界とした.

数值解析はジオテキスタイルと摚拌混合杭の効果に着目して以下に示す検討項目に従い，ケーススタデ イを実施した。

(1)盛土高さの違いにおける本工法の効果.

(2)パンチング破壊防止のために敷設したジオテキスタイルの補強効果.

(3)動的載荷荷重の違いによる地盤の挙動.

表-2に今回の解析ケースを示す．盛土高さ，ジオテキスタイルの有無，動的荷重をパラメータとした 9 ケースの計算を行った. 解析は静的解析により自重解析を行い地盤の初期応力状態を決定した. その後, 静的解析により盛土構築による地盤の変形・応力を求めた後, 列車荷重に相当する動的荷重を載荷した. 動的荷重は，現場試験と同じ条件である正弦波，22Hzとし，現場で用いた載荷板と同一の載荷面積で載荷 した. 本検討は変形等が大きいと考えられる施工初期の列車荷重載荷時を想定し，加振初期の挙動に着目 した.

表-2 解析ケース

\begin{tabular}{|c|c|c|c|c|}
\hline ケース名 & 盛土高 & 改良杭の純问雨 & ジオテキスタイル & 功的荷 \\
\hline ケース1 (a) & $2.5 \mathrm{~m}$ & $1.5 \mathrm{~m}$ & 2 (2) $(60 \mathrm{kN} / \mathrm{m})$ & $\pm 60 \mathrm{kN}$ \\
\hline ケース 1 (b) & $2.0 \mathrm{~m}$ & $1.5 \mathrm{~m}$ & 2 凪 $(60 \mathrm{kN} / \mathrm{m})$ & $\pm 60 \mathrm{kN}$ \\
\hline ケース 1 (c) & $3.75 \mathrm{~m}$ & $1.5 \mathrm{~m}$ & 2 周 $(60 \mathrm{kN} / \mathrm{m})$ & $\pm 60 \mathrm{kN}$ \\
\hline ケース2 (a) & $2.5 \mathrm{~m}$ & $1.5 \mathrm{~m}$ & なし & $\pm 60 \mathrm{kN}$ \\
\hline ケース 2（b) & $2.0 \mathrm{~m}$ & $1.5 \mathrm{~m}$ & なし & $\pm 60 \mathrm{kN}$ \\
\hline ケース 2（c) & $3.75 \mathrm{~m}$ & $1.5 \mathrm{~m}$ & なし & $\pm 60 \mathrm{kN}$ \\
\hline ケース 3 (a) & $2.5 \mathrm{~m}$ & $1.5 \mathrm{~m}$ & 2 凪 $(60 \mathrm{kN} / \mathrm{m})$ & $\pm 120 \mathrm{kN}$ \\
\hline ケース 3 (b) & $2.5 \mathrm{~m}$ & $1.5 \mathrm{~m}$ & 2 周 $(60 \mathrm{kN} / \mathrm{m})$ & $\pm 180 \mathrm{kN}$ \\
\hline ケース 3（c） & $2.5 \mathrm{~m}$ & $1.5 \mathrm{~m}$ & 2 屈 $(60 \mathrm{kN} / \mathrm{m})$ & $\pm 240 \mathrm{kN}$ \\
\hline
\end{tabular}

\section{2 解析結果}

(1)盛土施工に伴う応力について

図 $-4,5$ に盛土施工後のジオテキスタイルを2層敷設した場合（ケース1（a）〜（c））の地盤面での 鈶直応力分布（圧縮が正），ジオテキスタイルの張力（引張りが正）を示す．図中に示す距離は，モテル 左端からの距離である．擋汼混合杭の施工位置は $1.25 ， 3.75,6.25 \mathrm{~m}$ である. 図-4に地盤面での鈶直応力 分布を示す. 杭頭部において応力が集中し, 杭の施工されていない中間部の応力と比べ約4〜6倍の大きさ となった．また，盛土高さによる違いを見ると，盛土高さの増加率とほぼ同程度の割合で杭頭部における

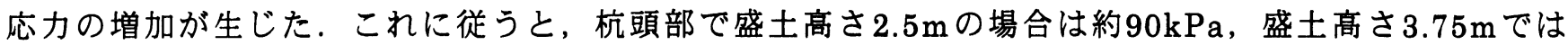
$120 \mathrm{kPa}$ となる，実際の現場における盛土高さ $3.0 \mathrm{~m}$ の場合を推定すると $100 \sim 110 \mathrm{kpa}$ 程度となる．参考文 献 1 にると現場での測定結果が $70 \mathrm{kPa}$ となった. 実測值と比較すると, 若干大きめの值となっているがほ 
ぼ解析值は実際の現場での值を模擬しており，モデルの妥当性が確認された。よって，以降のパラメータ ケーススタディはこのモデルを用いた。ここで生じた実測と解析の鉛直応力の差は, 一軸圧縮強度から推 定した改良体の物性値が要因の1つであると考えられる. 図-5に示すジオテキスタイルの張力においては, 杭頭部の方が杭中間部よりも上首のジオテキスタイルで3〜 4倍程度, 下層で $1.5 \sim 2$ 倍程度大きい值となっ た. また, $0.3 \mathrm{~m}$ 上首の方が下層と比べて, 杭頭部で 2 倍程度, 大きな張力が発生していた. 盛土高さでは, 鈶直応力同様, 高さに応じて差が生じ, 盛土高さが約 1.8 倍となると鈶直応力は約 1.3 倍の増加となった.

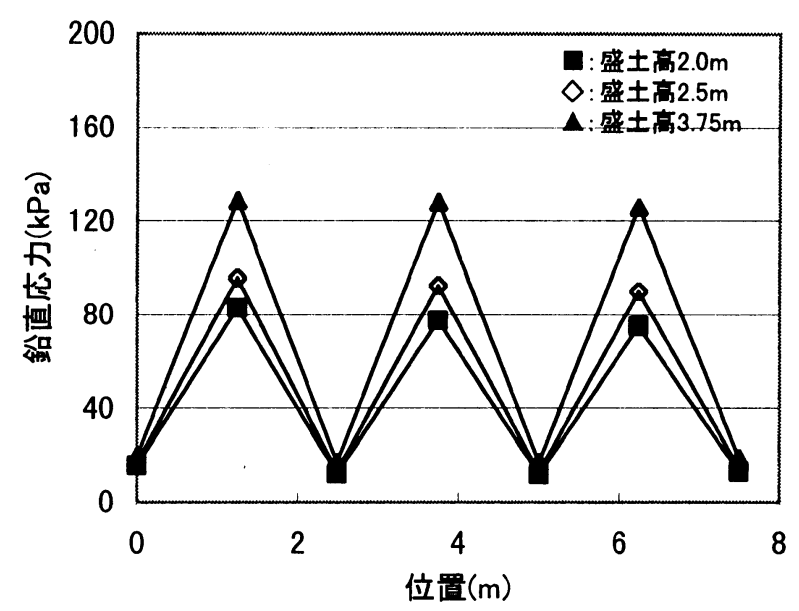

図-4＼cjkstart地盤面での鉛直応力分布

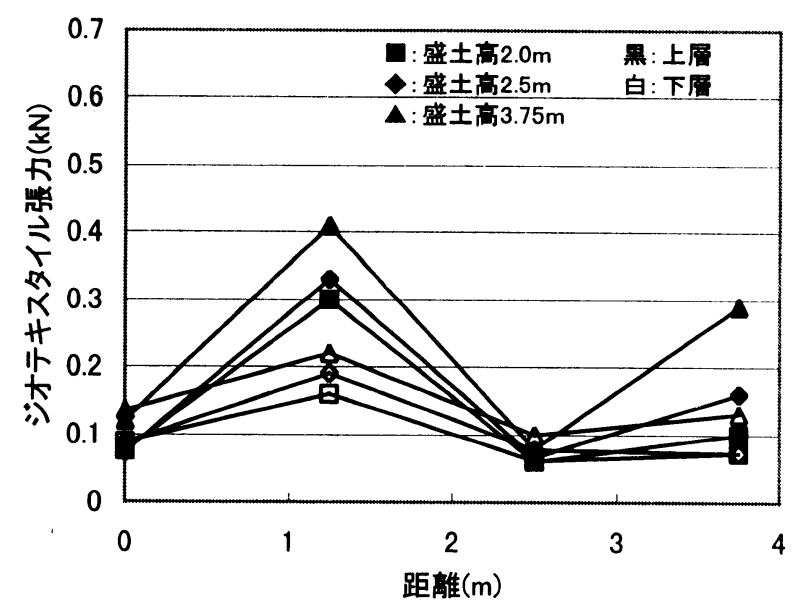

図-5 ジオテキスタイルの張力分布

(2)盛土高さの影響について

ケース 1 ( a ）〜（c）の比較から盛土高さの違いによる地表面での鈶直応力, 鉛直変位, ジオテキス タイルの張力について比較検討を行った. 検討は, 杭中間部（計測点 $\mathrm{A}$ ）と杭頭部（計測点 $\mathrm{B} ）$ の点を抽 出し, 盛土施工終了後を初期状態として動的載荷に伴う增分で検討を実施した. 図-6に杭中間部, 図-7に 杭頭部の動的載荷に伴う鈶直応力を示す. 杭中間部では, 盛土高さが $2.0 \mathrm{~m}$ と $2.5 \mathrm{~m}$ では有意な差はないが, $3.75 \mathrm{~m}$ になると鈶直応力は小さくなっており，盛土高さが約 1.8 倍になるにしたがい鈶直応力は約 0.7 倍と なった．杭頭部では杭中間部ほど盛土高さによる差はないが，若干，盛土高さの高い方が小さな応力とな った. また，杭中間部と比較して，杭頭部では約5倍の応力が発生し，杭の部分への応力集中が司える.ま た繰返し回数が增えるとともに，1〜3kPa とわずかではあるが鈶直応力は増加傾向にある. 図-8，9に鈶直 変位分布を示す. 図-8に示す杭中間部では載荷に伴う累積変位が顕著に現れている. また, 盛土高さが高 い $3.75 \mathrm{~m}$ の場合は他のケースと比較して沈下量やその增加率が小さく，盛土高さが $2.0,2.5 \mathrm{~m}$ 場合の約 1/2である. 杭頭部での鉛直変位を図-9に示すが, 盛土高さによる差は杭中間部ほど大きくない. 変位量に ついても, 杭中間部と比較すると $1 / 2 \sim 1 / 4$ 程度と小さかった. しかし, 盛土高さが低い $2.0 \mathrm{~m}$ の場合は変位 の增加率が非常に大きくなった. 図-10には杭中間部のジオテキスタイルの張力を示す. 載荷に伴い, 張力 が増加していくことが解る．鈶直変位同様，盛土高さが高い方が張力やその増加率も小さく，その差は鉛 直変位における比率とほぼ一致している. 図-11は杭頭部のジオテキスタイルの張力であるが, 杭中間部と 
比較して小さい. 載荷に伴い張力は增加するが, その増加率についても杭中間部と比べると小さいことが 解る. 盛土高さによる差は, あまり大きくなく $0.001 \mathrm{kN}$ 程度であった.

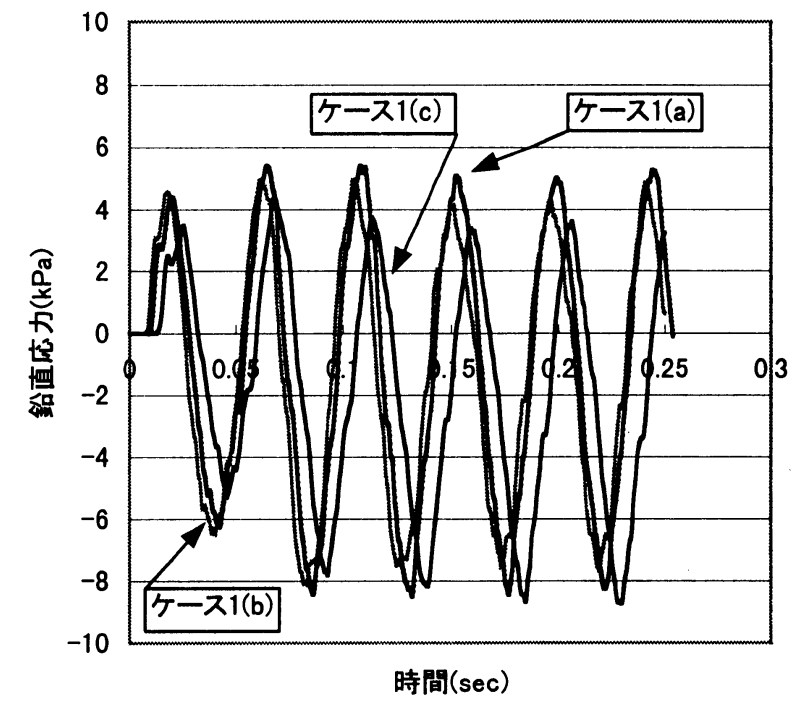

図-6 動的載荷時の地盤面の鉛直応力（杭中間部）

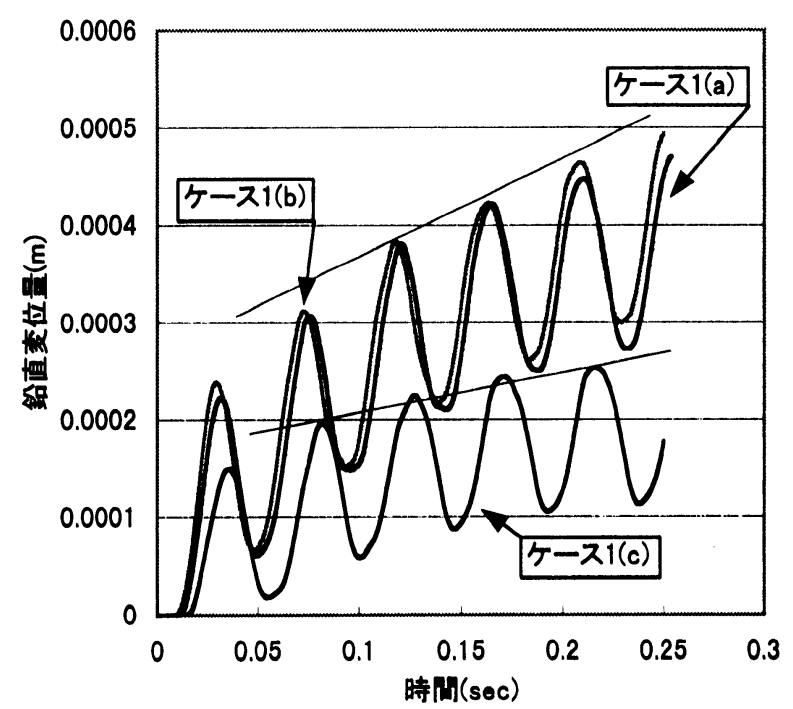

図-8 動的載荷時の地盤面の鈶直变位（杭中間部）

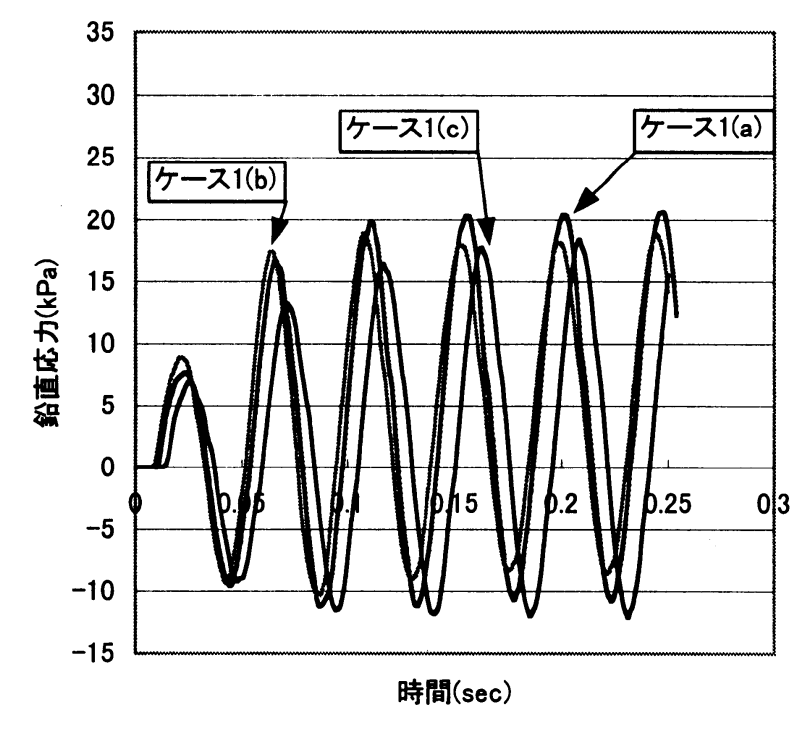

図-7 動的載荷時の地盤面の鈶直応力（杭頭部）

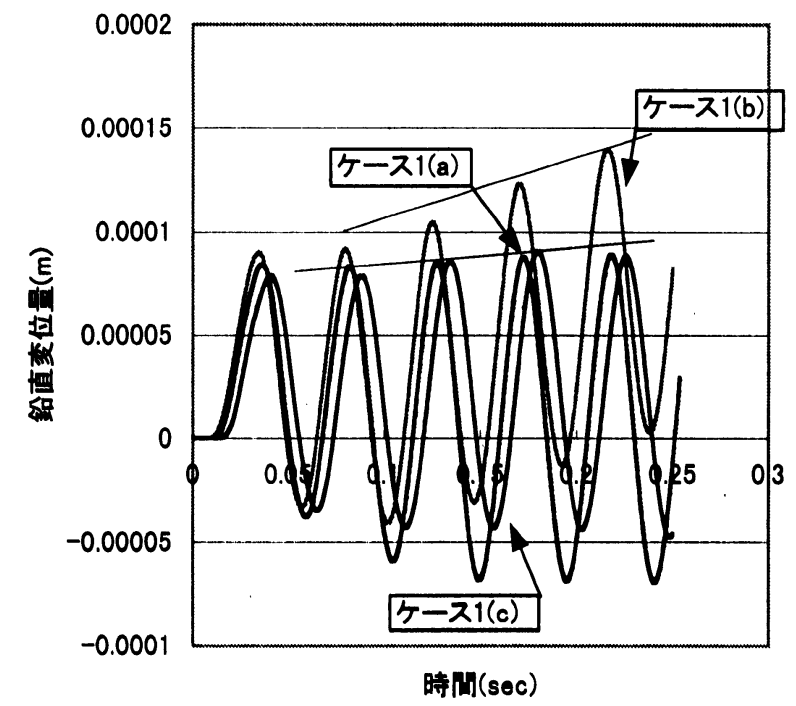

図-9 動的載荷時の地盤面の鈶直変位（杭頭部） 


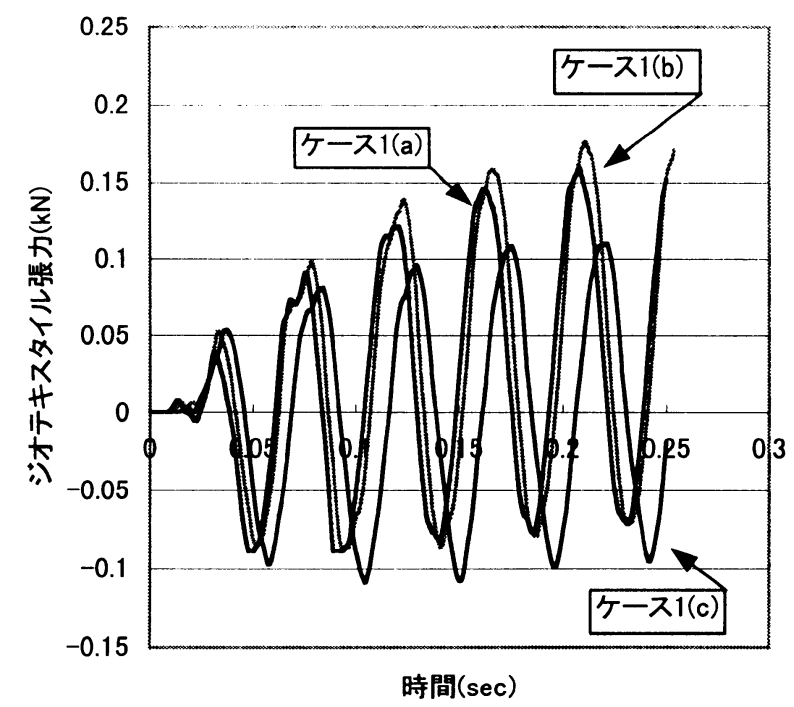

図-10 動的載荷時のジオテキスタイルの張力 (杭中間部)

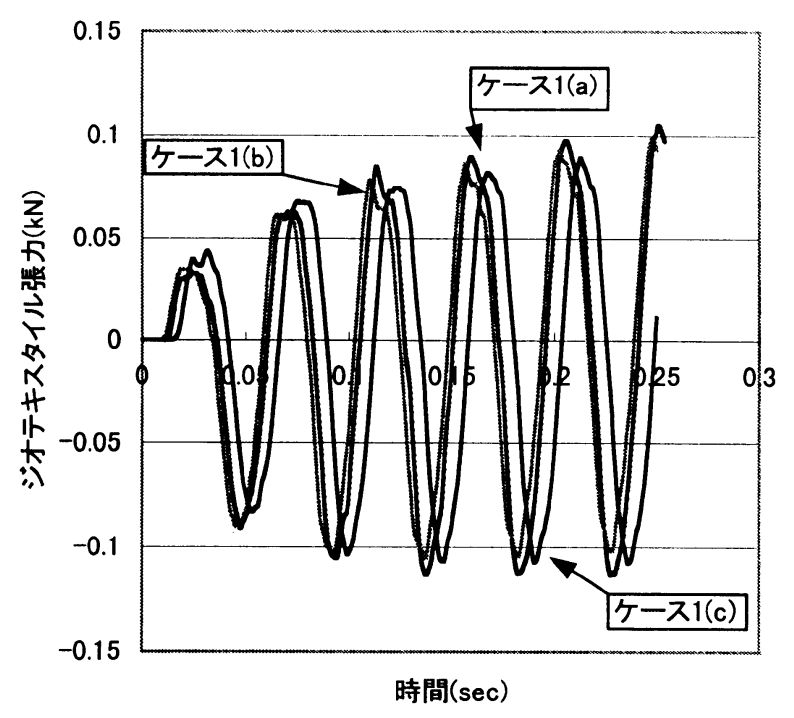

図-11 動的載荷時のジオテキスタイルの張力 (杭頭部)

(3) ジオテキスタイルの効果について

ケース 1（a）とケース 2（a）を比較することにより，ジオテキスタイル敷設による補強効果を比較 した．図-12に地盤面での鉛直応力を示す. 図中太線が杭頭部, 細線は杭中間部である. ジオテキスタイル の有無によって大きな差は生じてない. 図-13に鉛直変位を示す. 杭中間部において $10 \%$ 程度ジオテキスタ イルのない場合の方が大きな変位となり，ジオテキスタイル敷設による効果が現れている．杭頭部につい ては，ほとんど違いが生じなかった。

(4)動的荷重の違いについて

ケース 1（a ）, ケース 3（a ）～（c）の比較から, 動的載荷重の違いによる挙動の違いを比較した. 図-14に杭中間部での鉛直応力を示す。ケース 1 （a ）の4倍の載荷を行うと，10倍近い鉛直応力の増加が 生じた．杭頭部での值を図-15に示すが，杭頭部ではあまり大きな增加は見られず，4倍の載荷荷重に対し て2.5倍程度の増加となった．図-16は杭中間部の鉛直変位である. 鉛直応力の増加とほぼ同様に, 載荷荷 重が4倍となると 10 倍程度の変位の増加が生じた. 変位の増加率は載荷荷重の大きい方が大きく, 載荷荷 重が4倍となると約 10 倍の差がある. 杭頭部の鉛直変位を図-17に示すが，4倍の載荷荷重の増加に対し， 約5倍の鈶直変位の増加である. 載荷荷重の増加と鈶直変位の増加の比は, 杭中間部で約 2.5 , 杭頭部で約 1.25 と荷重レベルによらずほぼ一定であることがわかる. ジオテキスタイルの張力を図-18, 図-19に示す. 
杭中間部である図-18を見ると, 鉛直応力, 鉛直変位同様, 4倍の載荷荷重に対し5〜6倍程度の張力の増加 が見られる. 図-19に示す杭頭部では，4倍の載荷荷重の増加に対し，4〜5倍となった.

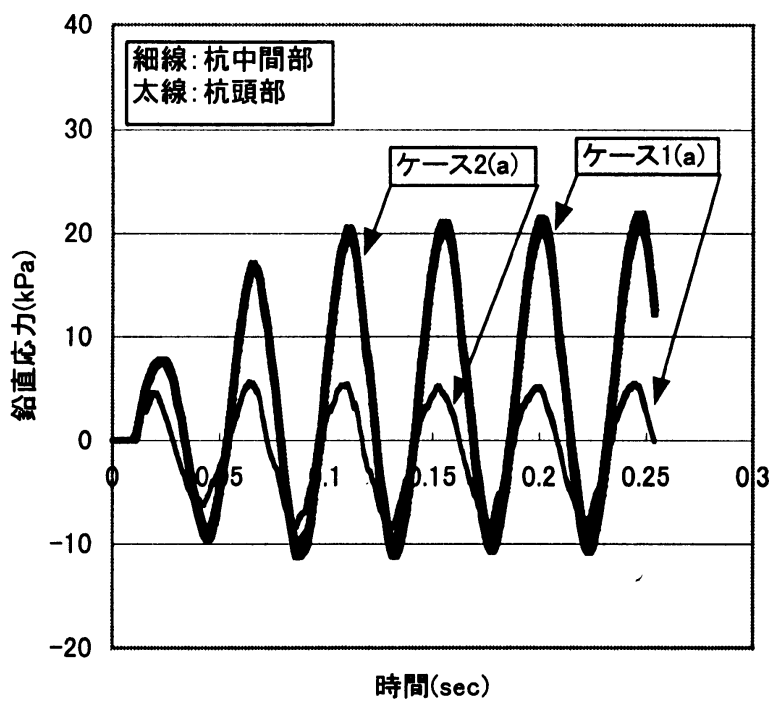

図-12 動的載荷時の鉛直応力

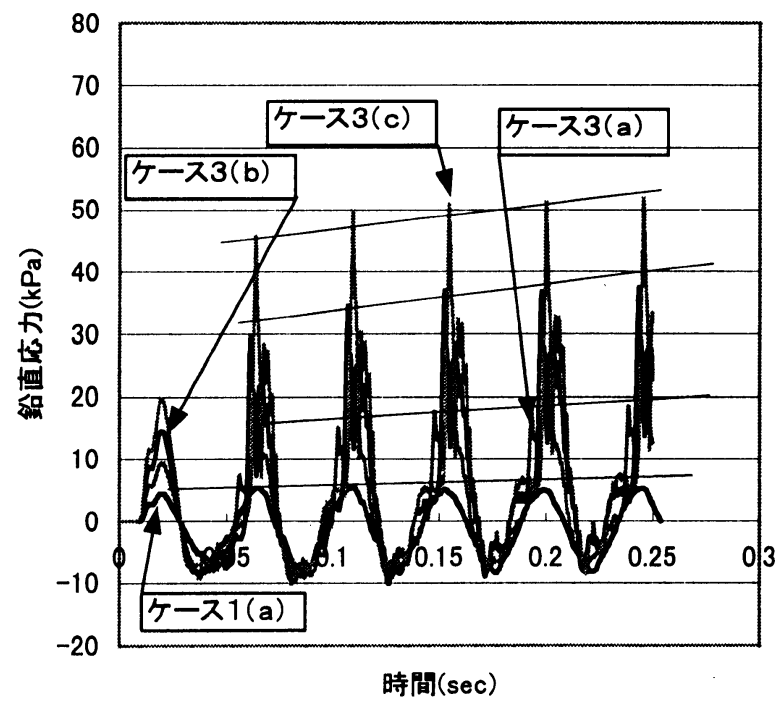

図-14 動的載荷時の鉛直応力（杭中間部）

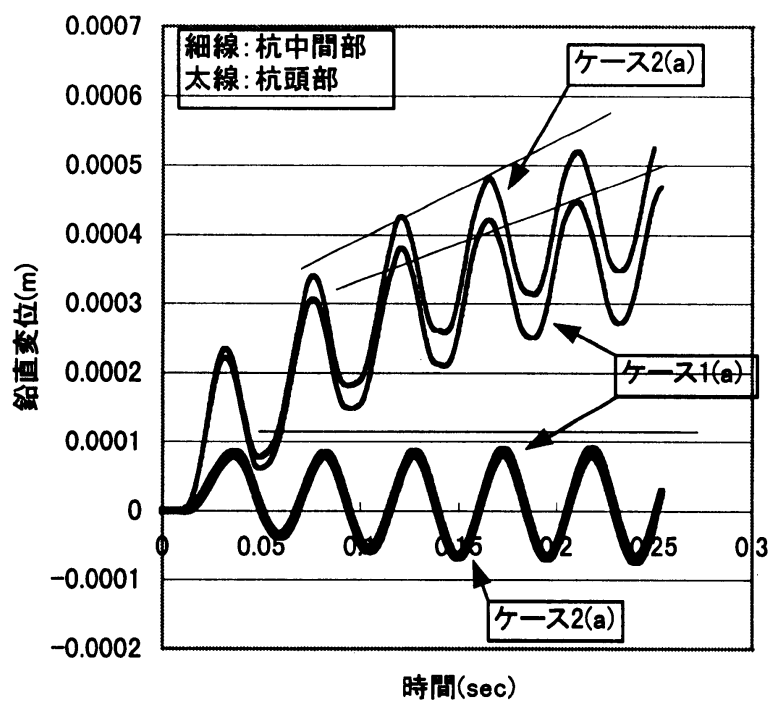

図-13 動的載荷時の鉛直変位

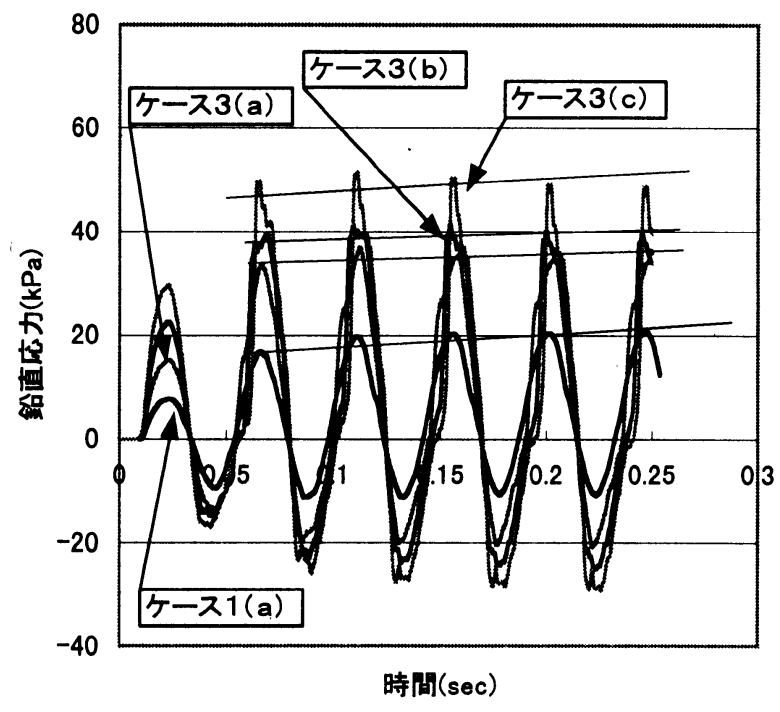

図-15 動的載荷時の鈶直応力（杭頭部） 


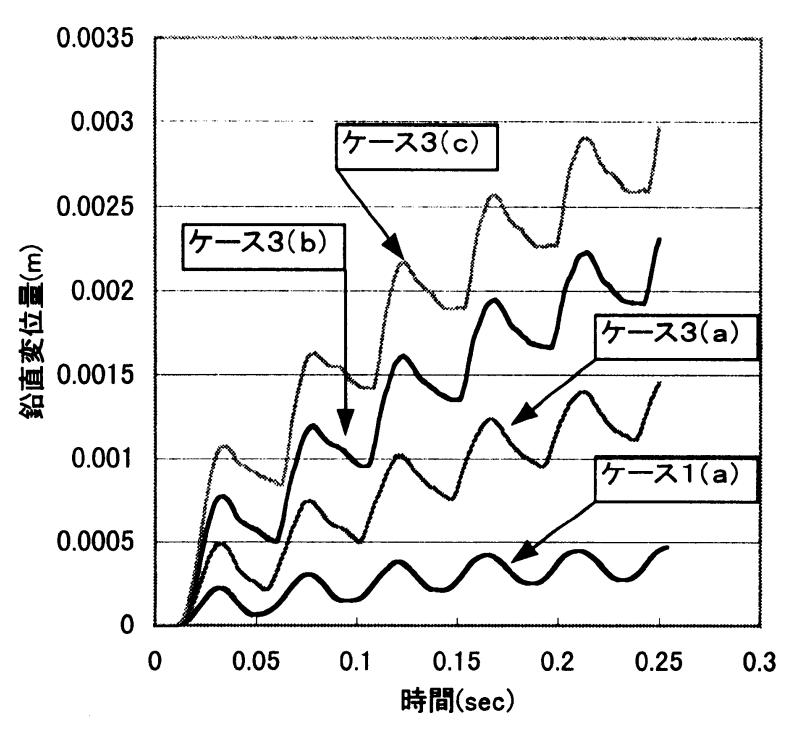

図-16 動的載荷時の鈶直変位（杭中央部）

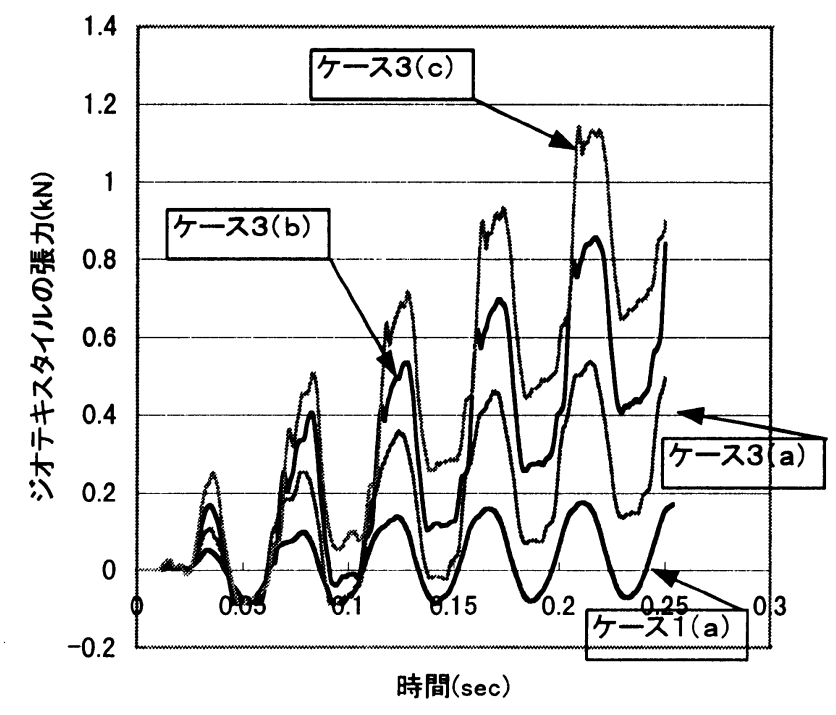

図-18 動的載荷時のジオテキスタイルの張力 (杭中央部)

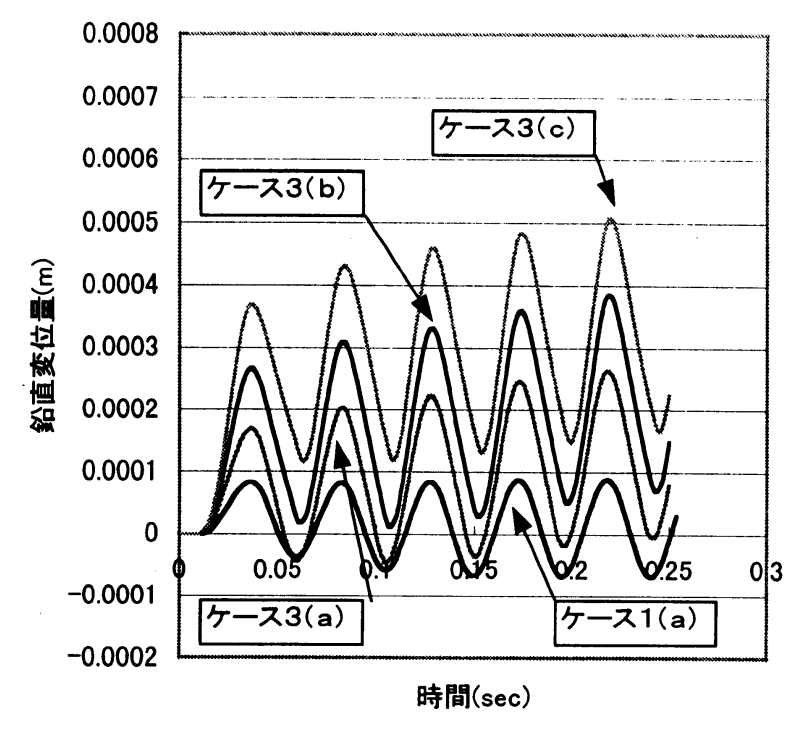

図-17 動的載荷時の鈶直変位（杭頭部）

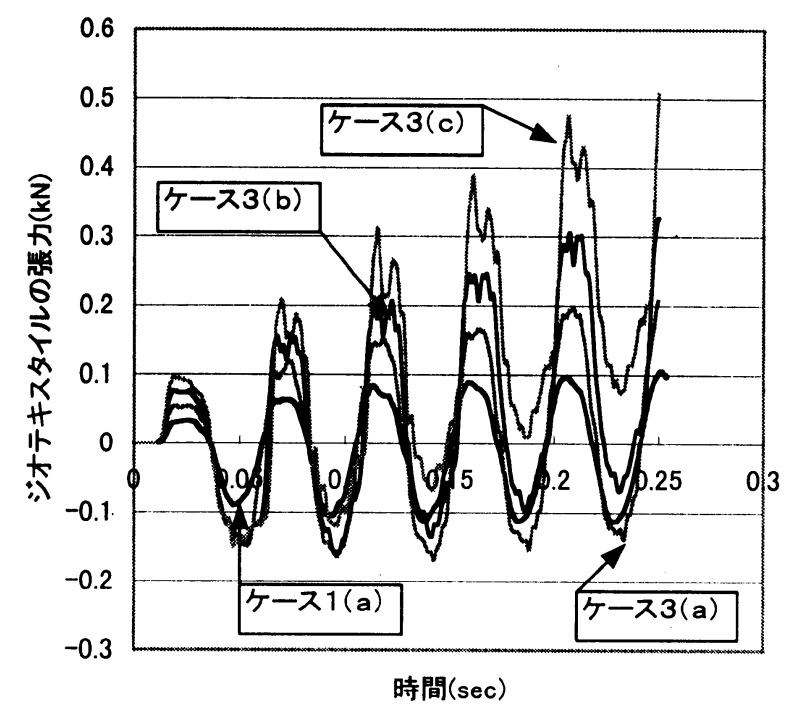

図-19 動的載荷時のジオテキスタイルの張力 (杭頭部)

\section{4.結論}

盛土高さ, ジオテキスタイルの有無, 動的載荷荷重をパラメータとして, 擋拌混合杭とジオテキスタイ ルによる軟弱地盤上盛土の変形抑止対策工法の効果について, 有限差分法による数值解析を用いて検討し, 以下の結果を得た。 
(1)盛土高さを高くすることにより, 地盤面における動的荷重は減少し, 鉛直応力は, 盛土高さが約 1.8 倍に なると 0.7 倍程度となった．鈶直変位においては，杭中間部と杭頭部において挙動が大きく異なり，杭中間 部では変位の累積が顕著であったが，杭頭部ではあまり変位の累積は生じなかった．杭中間部では盛土高 さの低いものの変位は特に大きく, 変位の增加率についても杭中間部では約 0.6 倍程度の盛土高さに対して 約 2 倍となり, 非常に大きくなることがわかった. 逆に, 杭頭部では杭の強度が高いため, あまり盛土高さ による違いはなかった。

(2)ジオテキスタイルの有無により，ジオテキスタイルの効果を比較検討した. しかし，杭中間部の鈶直変 位において, 若干, ジオテキスタイルを敷設した方が小さな值となったが, 今回検討を行った荷重レベル では顕著な差は見られなかった。

(3)動的荷重を2，3，4倍と增加させたときの, 地盤の挙動について比較を行った，杭中間部では鈶直応力， 鈶直変位, ジオテキスタイルの張力のいずれにおいても, 載荷荷重を增加させるとほぼ同程度の割合（約 1.5倍）で増加率が増加した. 杭頭部においても, 杭中間部ほど顕著ではないがいずれの值も若干の増加が 生じた．以上の結果より，杭中間部においてジオテキスタイルが受け持つ応力が大きいことが解る. 載荷 荷重の増加率と同程度の増加が見られた。これより，杭中間部においてはジオテキスタイル受け持つ応力 が非常に大きいことが確認でき，本工法が有効に機能していることがわかる.

今回の解析から動的荷重載荷時において, 杭中間部と杭頭部では鈶直応力や鈶直変位が大きく異なった. 実測值の傾向同様, 杭頭部では鈶直応力が高く, 鈶直変位が小さくなった. 特に変位については, 大きく 挙動の傾向が異なり杭中間部での変位の累積速度が盛土高さや動的荷重によって異なり, それと同時にジ オテキスタイルの張力が同様な挙動を示した．今回検討した各パラメータについては, 盛土高さが増加す ると荷重分散効果により地盤に伝わる鈶直応力や鈶直変位, ジオテキスタイルの張力が減少することが確 認された．また，動的荷重に関しては盛土高さ以上に差が大きいことが解った。

本検討では各パラメータにおけるケーススタティとして, 比較的変形などの変化が大きい動的載荷初期 に着目し，検討を行った．載荷初期においても，図-6,7に示すように鈶直土圧についてはほぼ定常となっ たが，沈下やジオテキスタイルの張カついては累積傾向にあり，長期的な繰返し載荷における検討が必要 であると考えられる. 今後は現場での試験結果を踏まえ，本工法の効果・特徵を評価し合理的な設計法へ 反映する予定である.

参考文献

(1)村上明, 青木一二三, 米澤豊司, 矢崎澄雄, 舘山勝, 小島謙一 : 深層混合処理とジオテキスタイル併用 工法による軟弱地盤上盛土の現地動的繰返し載荷試験, 第14回ジオシンセティックスシンポジウム, 2000.12 . 